Mesopotamia J. of Agric. (ISSN 1815 - 316X) Vol. (38) No. (Supplement 1) 2010

\title{
INCREASING PRODUCTIVITY OF HEAD LETTUCE BY FOLIAR SPRAYING OF SOME BIO AND ORGANIC COMPOUNDS
}

\author{
Zakaria Fouad Fawzy \\ Vegetable Crops Department - National Research Centre, Dokki, Cairo, Egypt.
}

\begin{abstract}
Two field experiments were conducted during the two successive winter seasons of 2004/2005 and 2005/2006 at Berkash cv. Lymor (9283) to foliar spray by dry yeast at a rate of ( 2 and $4 \mathrm{~g} / \mathrm{L}$ ), amino green compound at a rate of ( 2 and 4 $\mathrm{ml} / \mathrm{L}$ ) and humic acid at a rate of $(2$ and $4 \mathrm{ml} / \mathrm{L})$ on growth, yield and s"Giza Governorate" to investigate the response of head lettuce plants ome chemical contents of head lettuce plants. The results indicated that, application of amino green compound as a foliar spray at a rate of $4 \mathrm{ml} / \mathrm{L}$ gave the maximum number of head lettuce leaves compared with other treatments. In addition, the highest values of leaf dry weight, head fresh weight, total yield of heads and quality ( ascorbic acid and T.S.S ) were obtained by foliar application of $4 \mathrm{~g} / \mathrm{L}$ dry yeast.The lowest amount of $\mathrm{N}^{-\mathrm{NO}_{3}}$ in leaves of head lettuce was recorded by using humic acid as a foliar spray at a rate of $4 \mathrm{ml} / \mathrm{L}$. On the other hand, the highest amount of $\mathrm{N}-\mathrm{NO}_{3}$ was recorded when amino green compound was used as a foliar spray at a rate of 4 $\mathrm{gm} / \mathrm{L}$. The highest content of $\mathrm{N}$ and $\mathrm{P}$ as well as Fe, Mn and $\mathrm{Zn}$ were recorded by foliar spray of dry yeast at a rate of $4 \mathrm{ml} / \mathrm{L}$. Meanwhile, the highest amount of $\mathrm{K}$ given when humic acid was sprayed at a rate of $4 \mathrm{ml} / \mathrm{L}$.
\end{abstract}

\section{INTRODUCTION}

Head lettuce (Lactuca sativa L.) is the world's most used salad crop. It is one of the important leafy vegetable crops which are eaten fresh and is a major and extensively grown cool season vegetable best adopted to temperate locations (Rubatzky and Tamaguchi, 1997). Dry yeast is a natural bio-substance suggested to be of useful stimulatory, nutritional and protective functions when it is applied on to vegetable plants during stress conditions due to its content of hormones, sugars, amino and nucleic acids, vitamins and minerals. Thereby, it can be induce thermatolerance due to its role in the synthesis of protein and nucleic acids and in minimizing their degradation (Natio et a.l, 1981). Many investigations cleared out that, application of dry yeast as a foliar spray was found to increase growth, yield and quality of some vegetable crops. (Abdel Aziz 1997, Fathy and Farid 2000 on some vegetable crops, Abou El-Nasr et a.l, 2001 on squash, Fathy et al 2002 and Khedr and Farid 2002 on tomato plants, Tarek 2003 and Mona et al, 2005 on cucumber plant). Amino green compound contains (w/v) told organic acids plus amino acids $15 \%$ and some microelements such as iron, zinc and manganese. Micronutrients in yeast and amino green compound play a very important role in vital processes of plants. They improve photosynthesis which intensifies the assimilating activity of the whole plants (Marschner, 1995). Zinc in plants is involved in enzymatic relations. One of the most important functions of zinc shows that starch synthesis is widely interrupted at zinc deficiency. It was also added that zinc plays also an important role in protein synthesis from amino acids and in decarboxlation of pyruvate. Concerning iron, Derar et al., 1996 observed that using Received 19/9/2010 accepted 4/10/2010 
some materials containing Fe as a foliar spray significantly increased growth and yield of beans. Humic acid is particularly used to decrease the negative effects of chemical fertilizers and could have beneficial effect on the nutrition of the plant (Martinez et al., 1983). The commercial humic acids were found to improve growth, yield production, quality and increased significantly in the accumulation of $\mathrm{P}, \mathrm{K}, \mathrm{Ca}, \mathrm{Mg}, \mathrm{Fe}, \mathrm{Zn}$ and $\mathrm{Mn}$ in tissues of some vegetable crops (David et al 1994, Padem and Ocal 1999 and Erik et al., 2000). This work was carried out to study the effect of dry yeast, amino green compound and humic acid as a foliar spray on the growth, yield and chemical contents of head lettuce plants.

\section{MATERIALS AND METHODS}

The present investigation was carried out during the two successive seasons of 2004/2005 and 2005/2006 at Berkash Giza Governorate, to study the effect of 7 treatmentsas a foliar application .i.e., dry yeast, amino green compound and humic acid at two rates for eash compared with the control (spray with water only) on growth, yield and chemical content of lettuce plants. Seeds of head lettuce (Lactuca sativa L.) cv. Lymar (9283) were drilled in foam trays of 209 holes in a media consisting of peatmoss and vermiculite 1:1. Trays were wetted and warmed under plastic sheet for three days, then kept under plastic tunnel. Normal nursery treatments were followed till seedlings become suitable for transplanting. The time of transplanting took place $15^{\text {th }}$ and $19^{\text {th }}$ of November in both seasons, respectively. The seeds of head lettuce was cultivated in Mid. September in the two seasons of study. The experiment included seven treatments as follows:

1- Foliar spray with water (control).

2- Foliar spray with amino green compound at a rate of $2 \mathrm{ml} / \mathrm{L}$.( Amino 1)

3- Foliar spray with amino green compound at a rate of $4 \mathrm{ml} / \mathrm{L}$.( Amino 2 ).

4- Foliar spray with dry yeast at a rate of $2 \mathrm{~g} / \mathrm{L}$. ( Yeast 1 ).

5- Foliar spray with dry yeast at a rate of $4 \mathrm{~g} / \mathrm{L}$. ( Yeast 2)

6- Foliar spray with humic acid compound at a rate of $2 \mathrm{ml} / \mathrm{L}$. (Humic 1)

7- Foliar spray with humic acid compound at a rate of $4 \mathrm{ml} / \mathrm{L}$. (Humic 2)

Plants were sprayed with dry yeast, amino green compound and humic acid solution at 4 and 6 weeks after transplanting. Pest control and other agriculture practices, such as cultivation and irrigation, etc. were applied wherever it was necessary and as commonly recommended in the commercial head lettuce production. Harvesting was carried out 85 and 91 days after transplanting in the first and second seasons, respectively.With regard to the chemical analysis of the dry yeast, N.R.P 1977 stated that, the analysis of dry yeast was protein $(47.2 \%)$, arginine $(2.6 \%)$, glycin $(2.6 \%)$, histidin $(1.4 \%)$, islysine $(2.9 \%)$, lauicine $(3.5 \%)$, Lysine $(3.8 \%)$, methionine systine $(0.6 \%)$, phnyl-alanine $(3 \%)$, tyrosine $(2.1 \%)$, threonine $(2.6 \%)$, tryptophan $(0.5 \%)$ and vitamin B $(2.9 \%)$. Goyal and Khuller (1992), Yatskovskaya et al (1992), Murakami et al (1996) Ahmed et al (1997) and Khedr and Farid (2002) reported that, yeast preparation contained carbohydrates, sugars, proteins, fatty acids, amino acids, hormones, macro and micro elements in suitable balance. Amino green compound contains (w/v) total organic acids plus amino acids $15 \%$, iron $(\mathrm{Fe}) 2.9 \%$, zinc $(\mathrm{Zn}) 1.4 \%$ and manganese $(\mathrm{Mn}) 0.7 \%$, free amino acids, proline, hydroxy proline, glycine, alanine, valine, methionine, 
escaliosin, lysine, cycteine, phenylalanine, serine, glutamic, arginine, histidine, lysine and hystiden.Humic acid compound contains humic acid $25.0 \mathrm{~g} / \mathrm{L}$, Folic acid $0.7 \mathrm{~g} / \mathrm{L}$, nitrogen $4.0 \mathrm{~g} / \mathrm{L}$, phosphorus $0.6 \mathrm{~g} / \mathrm{L}$ and potassium $8.0 \mathrm{~g} / \mathrm{L}$. This compound from theorem will be reformed to as "humic acid" . The experiment was arranged in a complete randomized block design in four replicates. Six plants of each plot were chosen randomaly at 75 days after transplanting and the following data were recorded.

\section{A- Vegetative growth:}

1- Number of leaves/ plant.

2- Dry weight of leaves/ plant (g).

\section{B- Yield:}

1- Average head weight ( $\mathrm{g}$ )

2- Total yield (Ton/fed.)

\section{C- Chemical content:}

Samples of heads were taken at harvesting time. Ascorbic acid (vitamin C $\mathrm{mg} / 100$ ) and Total soluble solids (T.S.S) were determined according to A.O.A.C (1984). Nitrate-N content in the fresh head lettuce leaves was determined using the method of Wooley et al., (1960). Samples of leaves were oven dried at $70^{\circ} \mathrm{C}$ then fine grounded and wet digested. Total nitrogen, phosphorus and potassium concentration in the tissues of plant leaves were determined according to the methods described by Jackson (1958) Troug and Mayer (1939) and Brown and Lilleland (1946), respectively. Some micro-elements, i.e. Fe, $\mathrm{Zn}$ and $\mathrm{Mn}$ were determined using Atomic Spectrophotometer (Phillips) according to Chapman and Pratt (1961). Data obtained were subjected to the statistical analysis according to the method of Gomez and Gomez (1984).

\section{RESULTS AND DISCUSSION}

Data in Table (1) show clearly that, using dry yeast, amino green and humic acid as a foliar spray on head lettuce plants increased vegetative growth characters compared with the control treatment except for dry weight of leaves in the second season of the study. The highest number of leaves was recorded by using $4 \mathrm{ml} / \mathrm{L}$ amino green in the two seasons. On the contrary, the lowest number of leaves was found in case of the control treatment. These findings were true in both seasons. These results may be due to the physiological roles of amino acids in the amino green which increased the metabolic processes rate, and in the same time it is cells that each micronutrient in the amino green compound has a role in improving plant growth. $\mathrm{Zn}$ directly involved in the synthesis of the in dole acetic acid (IAA). Mn is directly involved in the catalytic rates in plants being the enzyme activator on some respiratory enzymes and in reaction of nitrogen metabolism and photosynthesis (Marschner 1995). These results may be attributed to the effect of yeast extract in increasing levels of endogenous hormones in treated plants which could be interpreted by cell division and cell elongation (Khedr and Farid، 2002). In addition, these results may be due to the physiological roles of vitamins and amino acids in the yeast extract which increased the metabolic processes role and levels of indogenous hormones, i.e. IAA and $\mathrm{GA}_{3}$ (Chailakhyan، 1957). 
Table(1): Effect of foliar spray of amino green, yeast and humic acid on leaf number and leaves dry weight of head lettuce plants in 2004-2005 and 2005-2006 seasons.

\begin{tabular}{|l|c|c|c|c|}
\hline \multirow{2}{*}{ Treatments } & \multicolumn{2}{|c|}{$2004-2005$} & \multicolumn{2}{c|}{ 2005-2006 } \\
\cline { 2 - 5 } & $\begin{array}{c}\text { Leaves } \\
\text { Number }\end{array}$ & $\begin{array}{c}\text { Leaves dry } \\
\text { weight }(\mathrm{g})\end{array}$ & $\begin{array}{c}\text { Leaves } \\
\text { Number }\end{array}$ & $\begin{array}{c}\text { Leaves dry } \\
\text { weight }(\mathrm{g})\end{array}$ \\
\hline Control & 36.30 & 14.73 & 33.02 & 21.83 \\
\hline Amino 1 & 38.60 & 16.49 & 43.30 & 16.02 \\
\hline Amino 2 & 43.40 & 16.25 & 49.00 & 20.80 \\
\hline Yeast 1 & 38.01 & 16.60 & 40.00 & 23.41 \\
\hline Yeast 2 & 37.60 & 18.14 & 43.00 & 27.20 \\
\hline Humic 1 & 38.70 & 15.97 & 43.03 & 25.98 \\
\hline Humic 2 & 37.34 & 16.32 & 43.02 & 26.28 \\
\hline LSD at 5\% & 4.88 & 2.20 & 4.08 & 3.53 \\
\hline
\end{tabular}

The obtained results were in accordance with regarded of dry weight leaves. Data in Table (1) show that, the highest amount of dry weight of leaves was found by using foliar spray of dry yeast at a rate of $4 \mathrm{gm} / \mathrm{L}$. On the other hand, the lowest dry weight of leaves was given by foliar spray of water (control treatment) in the first season and by foliar spray of amino green at a rate of $2 \mathrm{ml} / \mathrm{L}$ in the second one. These increments due to using yeast as a foliar spray are agreement with those reported by Sonmez and Bozkurt (2006) and Tufenkei et al. (2006) on lettuce plants.

Total yield: As shown in Table (2), there were significant differences in the average head weight and total yield of head lettuce among the different foliar spray treatments. The highest average head weight and total yield were produced by using dry yeast at a rate of $4 \mathrm{~g} / \mathrm{L}$. On the contrary, the lowest head weight and total yield of head lettuce were recoded by the control treatment (foliar spray with water). These results held true in the two seasons of the study.

Table(2): Effect of foliar spray of amino green, yeast and humic acid on yield and quality of head lettuce plants in 2004-2005 and 2005-2006 seasons.

\begin{tabular}{|l|c|c|c|c|c|c|c|c|}
\hline Treatments & \multicolumn{4}{|c|}{$2004-2005$} & \multicolumn{4}{c|}{$2005-2006$} \\
\cline { 2 - 9 } & $\begin{array}{c}\text { Head } \\
\text { weight } \\
(\mathrm{g})\end{array}$ & $\begin{array}{c}\text { Total } \\
\text { yield } \\
\text { T/fed. }\end{array}$ & $\begin{array}{c}\text { Ascorbic } \\
\text { acid } \\
(\mathrm{mg} / 100 \mathrm{~g})\end{array}$ & $\begin{array}{c}\text { T.S.S } \\
\%\end{array}$ & $\begin{array}{c}\text { Head } \\
\text { weight } \\
(\mathrm{g})\end{array}$ & $\begin{array}{c}\text { Total } \\
\text { yield } \\
\text { T/fed. }\end{array}$ & $\begin{array}{c}\text { Ascorbic } \\
\text { acid } \\
(\mathrm{mg} / 100 \mathrm{~g})\end{array}$ & $\begin{array}{c}\text { T.S.S } \\
\%\end{array}$ \\
\hline Control & 282.74 & 7.07 & 6.21 & 3.10 & 450.81 & 11.27 & 7.30 & 3.20 \\
\hline Amino 1 & 412.16 & 10.30 & 7.11 & 3.61 & 502.69 & 12.57 & 8.10 & 3.52 \\
\hline Amino 2 & 459.93 & 11.50 & 7.50 & 3.72 & 557.95 & 13.95 & 8.40 & 3.74 \\
\hline Yeast 1 & 382.33 & 9.56 & 8.2 & 3.74 & 555.62 & 13.89 & 8.92 & 3.82 \\
\hline Yeast 2 & 510.19 & 12.75 & 8.44 & 3.82 & 589.66 & 14.74 & 9.40 & 3.86 \\
\hline Humic 1 & 390.21 & 9.76 & 6.70 & 3.02 & 581.20 & 14.53 & 7.45 & 3.30 \\
\hline Humic 2 & 495.53 & 12.39 & 6.92 & 3.64 & 587.32 & 14.68 & 7.78 & 3.40 \\
\hline LSD at5\% & 162.59 & 4.06 & 1.01 & NS & 105.50 & 1.14 & 0.97 & NS \\
\hline
\end{tabular}


The positive effect of applying active dry yeast was attributed to its own contents of different nutrients, high percentage of protein, large amounts of vitamin $\mathrm{B}$ and natural plant growth regulators such as cytokinins (Ahmed et al., 1997). These results agree with those reported by Abou El - Nasr et al., (2001) on squash, Fathy et al. (2002) on tomato plants, Tarek (2003) and Mona et al. (2005) on cucumber plant. Moreover, Abdel Aziz (1997) on tomato concluded that, using yeast $(5 \mathrm{~g} / \mathrm{L})$ solution significantly increased total yield of tomato plants. Also, using yeast preparation was the best treatment for growth and yield (136\% of control) of snap bean (Fathy et al., 2002)

\section{Chemical content:}

1- Ascorbic acid and T.S.S :As illustrated in Table (2) show that the highest values of ascorbic acid (vitamin C) and T.S.S were recorded by using dry yeast treatment at a rate of $4 \mathrm{~g} / \mathrm{L}$ without any significant with other treatments in case of Ascorbic acid. On the contrary, the lowest amount of Ascorbic acid and T.S.S were found by foliar spray with water (control plants). These results hold true in the both seasons. The trend of obtained results are in good accordance of the previous investigators such as Fathy et al, 2002 and Khedr and Farid 2002 on tomato plants.

2- Nitrate content in leaves: Data in Table (3) show the effect of foliar spray of the dry yeast, amino green compound and humic acid compared with the control (foliar spray of water) on nitrate content in leaves of head lettuce plants. The highest amount of nitrate content was found due to the spray of the amino green compound. On the other hand, the lowest amount of nitrate content was recorded by using foliar spray of humic acid at a rate of $4 \mathrm{ml} / \mathrm{L}$. without any significant difference between this treatment and using dry yeast treatment and /or the control treatment. These findings held true in both seasons of study.

Table(3): Effect of foliar spray of amino green, yeast and humic acid on chemical content of leaves of head lettuce plant in 2004-2005 and 2005- 2006 seasons.

\begin{tabular}{|c|c|c|c|c|c|c|c|c|}
\hline \multirow[b]{2}{*}{ Treatments } & \multicolumn{4}{|c|}{$2004-2005$} & \multicolumn{4}{|c|}{$2005-2006$} \\
\hline & $\begin{array}{l}\text { Nitrate } \\
\text { content }\end{array}$ & $\begin{array}{c}\text { Nitrogen } \\
(\%)\end{array}$ & $\begin{array}{l}\text { Phosphorus } \\
\text { (mg/100g) }\end{array}$ & $\begin{array}{l}\text { Potassium } \\
(\mathrm{mg} / 100 \mathrm{~g})\end{array}$ & $\begin{array}{l}\text { Nitrate } \\
\text { content }\end{array}$ & $\begin{array}{c}\text { Nitrogen } \\
(\%)\end{array}$ & $\begin{array}{l}\text { Phosphorus } \\
\text { (mg/100g) }\end{array}$ & $\begin{array}{l}\text { Potassium } \\
(\mathrm{mg} / \mathbf{1 0 0 g})\end{array}$ \\
\hline Control & 0.49 & 2.91 & 25.34 & 203.60 & 0.43 & 3.12 & 28.60 & 214.63 \\
\hline $\begin{array}{l}\text { Amino } \\
1\end{array}$ & 0.54 & 3.23 & 28.43 & 225.40 & 0.54 & 3.30 & 32.42 & 230.66 \\
\hline $\begin{array}{l}\text { Amino } \\
2\end{array}$ & 0.57 & 3.32 & 30.13 & 240.11 & 0.54 & 3.41 & 34.72 & 248.32 \\
\hline Yeast 1 & 0.48 & 3.07 & 29.70 & 260.70 & 0.42 & 3.34 & 38.70 & 270.30 \\
\hline Yeast 2 & 0.48 & 3.38 & 36.36 & 286.83 & 0.36 & 3.30 & 41.24 & 302.60 \\
\hline $\begin{array}{l}\text { Humic } \\
1\end{array}$ & 0.43 & 3.18 & 27.69 & 220.63 & 0.37 & 3.30 & 29.94 & 226.86 \\
\hline $\begin{array}{l}\text { Humic } \\
2\end{array}$ & 0.40 & 3.23 & 31.42 & 236.72 & 0.34 & 3.26 & 32.30 & 240.86 \\
\hline $\begin{array}{l}\text { LSD at } \\
5 \%\end{array}$ & 0.01 & NS & 3.13 & 12.72 & 0.06 & 0.06 & 2.66 & 17.55 \\
\hline
\end{tabular}


Nitrates are relatively nontoxic constituents in foods, but may be considered as a potential hazard, as they are the precursor of nitrites. If the nitrate ion is absorbed into the blood, the ferrious iron hemoglobin may be oxidized to the ferric form producing methemoglobin which cannot transport oxygen, especially in infants, and can reach with secondary amines to form carcinogenic nitrosamines, which cause cancer (Gunes et al, 1995). However, nitrate can be reduced to nitrite in the gastrointestinal tract of the human infant, and by microflora of human mouth. The formed nitrate presents a toxic hazard both because of the direct toxicity of nitriate and the formation of carcinogenic N-nitroso compound by reaction with amino compound (Swann, 1975). These results seem to be apparently in agreement with those reported by Fathy et al 2002 on tomato plants. With respect to the effect of the different treatments on nitrate accumulation in head lettuce leaves, the obtained results (Table 3) reflected different responses to the studied factors with respect to $\mathrm{NO}_{3}-\mathrm{N}$ content of head lettuce leaves. The application of amino green compound significantly increased the content of $\mathrm{NO}_{3}-\mathrm{N}$ in lettuce leaves, compared with control treatment. Meanwhile, the application of humic acid at a rate of $4 \mathrm{ml} / \mathrm{L}$ as a foliar spray caused a significant reduction in nitrate content compared with control. Concerning the effect of humic acid or dry yeast on nitrate content of lettuce leaves, it seems under conditions of the present study that, the application of humic acid or dry yeast resulted in the reduce the content of $\mathrm{NO}_{3}-\mathrm{N}$. That was found to be very important to human health, since, head lettuce leaves are used in fresh status. Similar results were found by Abd El-Fattah and Sorial (1998).

3- Mineral content in leaves of head lettuce plants: Foliar application of dry yeast, amino green compound and humic acid resulted in slight increases in head lettuce leaves content of N, P, K, Fe, Zn and Mn elements (Tables 3 and 4).

Table(4): Effect of foliar spray of amino green, yeast and humic acid on Fe, $\mathrm{Zn}$ and Mn content of leaves of head lettuce plants in 2004-2005 and 2005- 2006 seasons.

\begin{tabular}{|l|c|c|c|c|c|c|}
\hline \multirow{2}{*}{ Treatments } & \multicolumn{3}{|c|}{$2004-2005$} & \multicolumn{3}{c|}{$2005-2006$} \\
\cline { 2 - 7 } & $\begin{array}{c}\text { Fe } \\
(\mathrm{ppm})\end{array}$ & $\begin{array}{c}\mathrm{Zn} \\
(\mathrm{ppm})\end{array}$ & $\begin{array}{c}\mathrm{Mn} \\
(\mathrm{ppm})\end{array}$ & $\begin{array}{c}\text { Fe } \\
(\mathrm{ppm})\end{array}$ & $\begin{array}{c}\mathrm{Zn} \\
(\mathrm{ppm})\end{array}$ & $\begin{array}{c}\mathrm{Mn} \\
(\mathrm{ppm})\end{array}$ \\
\hline Control & 233.00 & 63.00 & 55.00 & 260.00 & 66.00 & 73.00 \\
\hline Amino 1 & 340.00 & 73.00 & 82.00 & 369.00 & 74.00 & 89.00 \\
\hline Amino 2 & 362.00 & 74.00 & 83.00 & 380.00 & 84.00 & 90.00 \\
\hline Yeast 1 & 352.00 & 76.00 & 90.00 & 413.00 & 78.00 & 130.00 \\
\hline Yeast 2 & 426.00 & 83.00 & 103.00 & 447.00 & 93.00 & 145.00 \\
\hline Humic 1 & 312.00 & 70.00 & 74.00 & 340.00 & 66.00 & 84.00 \\
\hline Humic 2 & 329.00 & 65.00 & 76.00 & 348.00 & 77.00 & 89.00 \\
\hline LSD at 5\% & 56.00 & 1.22 & 11.00 & 89.00 & 1.69 & 16.00 \\
\hline
\end{tabular}

The data in these tables indicate that there was a statisticaly significant effect for the foliar application treatments on the content of N, P, K, Fe, Zn and Mn elements in the leaves of head lettuce plants. The highest values of all elements were recorded by using dry yeast at a rate of $4 \mathrm{~g} / \mathrm{L}$ except for $\mathrm{K}$ element where the highest values were recoded by using foliar spray of humic acid at a rate of $4 \mathrm{ml} / \mathrm{L}$. On the 
contrary, the lowest values of all elements were found in case of the control plants (foliar spray of water). These result may be due to the content of macro and micro elements of the dry yeast, amino green and humic acid. El-Fouly 1983 reported that, foliar application of microelements is highly recommended under Egyptian conditions. In view of the fact the soil $\mathrm{pH}$ exceeds 7.5 and sometimes even 8.5 some areas show high $\mathrm{CaCO}_{3}$ contents which among other factors, make soil application of micronutrients more costly and unpractical. Also, the increases in pea yield and in the contents of microutrients in pea leaves due to the foliar application of micronutrients agree with the findings of Soliman 1996 Alphons and Saad 2000 on cucumber plant and El-Shal et al, 2002 on head lettuce plants.

\section{CONCLUSION}

The results of the present investigation indicated that, foliar application of dry yeast, amino green and humic acid, especially the application of dry yeast, stimulated most of vegetative growth characters of head lettuce plants and some chemical compounds of head lettuce leaves which led to producing higher head weight and total weight of head lettuce plants. The results of the present study also, support the fact that, the use of dry yeast as a foliar spray leads to increasing plant growth which causes significant increases in head weight and total yield of head lettuce plant.Nitrate content was lower when head lettuce plants were sprayed with $4 \mathrm{~g} / \mathrm{L}$ humic acid.

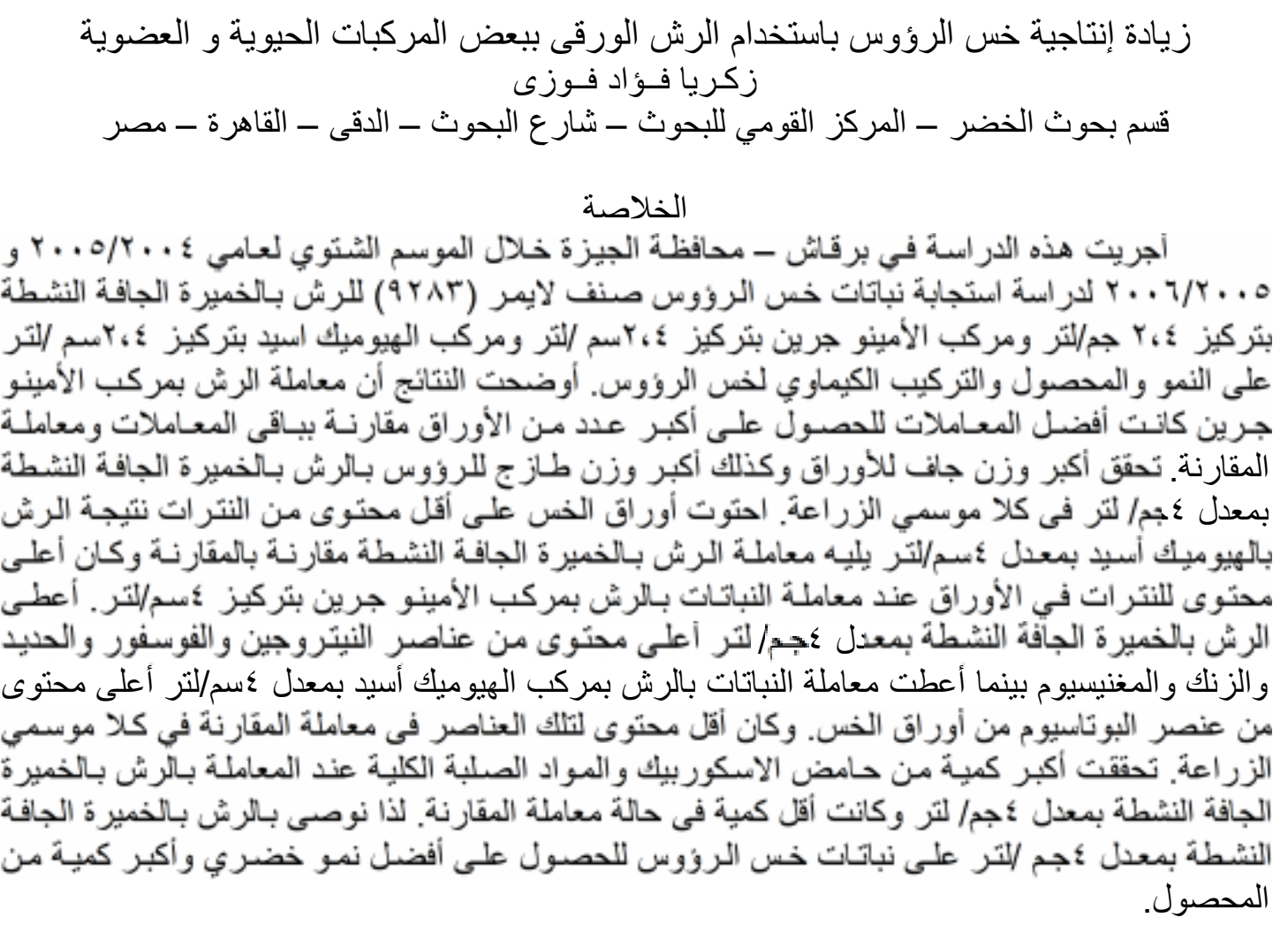

REFERENCES

A.O.A.C. (Association of official Analysis Chemists), (1984). Official Methods of Analysis, Virginia, USA. 
Abd EL-Fattah, M. A. and Merat E. Sorial. 1998. Efficiency of biofertilization on responses of the productivity and chemical composition of lettuce plants grown under different nitrogen levels. Menofiya. J. Agric. Res 23 (5): 1185-1207.

Abdel-Aziz, M. A. 1997. Response of tomato plants to nitrogen fertilizer levels and growth regulators. M.Sc. Thesis Fac. Agric. Cairo Univ. Egypt.

Abou El - Nasr, M.E., R.A. El - Shabrawy and M.M. Abd El - Rahman. 2001. Effect of Bread yeast application and some nutrient elements on squash ( Cucurbita pepo L ) plant growth, yield and fruit quality under conditions of the early summer planting .J. Agric. Sci. Mansoura Univ., 26 (7) : 4451 - 4464.

Ahmed, F.F., A.M. Aki; F.M. El-Morsy and M.A. Raggab. 1997. The beneficial effect of biofertilizer on red roomy grape vine (Vita vinfera $\mathrm{L}$ ). the effect on growth and vine nutritional status. Annals of Agric. Sci, Moshtohor. 35 (1): 489-495.

Alphons, M and E.M. Saad. 2000. Effect of organic media and micronutrients on mineral contents of plastic house cucumber. Egypt. Sci,. Hort. 27 (3): 385-408.

Brown, J. D. and O. Lilleland. 1946. Rapid determination of potassium and sodium in plant material and soil extract by flame photometry. Proc. Amer. Hort. Sci., 39: 341-364.

Chaliakhyan, M. Kh. 1957. Effect of Vitamins on growth and development of plants. Dokly Akad. Nauk. SSSK, 111: 894-897.

Chapman, H. D. and P.F. Pratt. 1961. Methods of analysis for soil, plant and water. California Univ. USA.

David, P.P; P. V. Nelson and D.C. Sanders. 1994. A humic acid improves growth of tomato seedling in solution culture. Plant Nutr., 17 (1): 173-184.

Derar, R.A., E. N. Gendy and S.K. Saleep. 1996. Enfluence of gypsum and iron application on faba bean plants grown on alluvial soils. Egypt . J. Appl. Sci., 11 (3): 205-211.

El-Fouly. M.M. 1983. Micronutrients in arid and semiarid areas: Levels in soil and plants for fertilizers, with particular reference to Egypt. Proc. $17^{\text {th }}$ codoguium international potash Inst, Kakat and Marrakesh/ Morocco 11.

El-Shal, M.A.; E.M.; Helmy, M.A. El-Fattah and M.E. El-Kalash. 2002. Lettuce yield and quality as affected by different fertilization treatments and microelements application. $2^{\text {nd }}$ Enter. Conf. Hort. Sci. Kafr Kl-Sheikh, Tanta Univ. Egypt 235-561.

Erik, B; G. Feibert; C. Clint and L.D. Sunders. 2000. Evaluation of humic acid and other non conventional fertilizer additives for onion production. Malheur Experiment Station Oregon state university ontanio, or, 2000.

Fathy, E.S.L.; S. Farid and S.A. El Desouky. 2002. Induce cold tolerance of outdoor tomatoes during early summer season by using triphsphate (ATP), yeast, other natural and chemical treatments to improve their fruiting and yield. Agric. Sci. Mansoura Univ. 25 (1): 377-401.

Fathy, S.L. and S. Farid 2000. effect of some chemical treatments, yeast preparation and Royal Jelly on some vegetable crops growing in late summer season to induce their ability towards better thermal tolerance. J. of . Agric. Sci. Mansoura Univ. 25 (4): $2215-2249$.

Gomez, K. A. and A.A. Gomez. 1984. Statistical procedures for agriculture Research. Second Ed. Willey inter Science. PP. 357-423.

Goyal, S. and G.K. Khuller. 1992. Phospholipid composition and subcellular distribution in yeast and mycelial forms of Candida allicans. Sournal of medical and veterinary mycology 30 (5): 355-362.

Gunes, A., W. H. K. Post and M. Ktas. 1995. Effect of partial replacement of nitrate by $\mathrm{NH}_{4}-\mathrm{N}$, Urea-N and amino acid $-\mathrm{N}$ in nutrient solution and nitrate accumulation in lettuce. Agrochemica, 39: 326-333. 
Jakson, M.L. 1958. Soil chemical analysis prentice. Hall, Inc. Enlewood Cliffs, N. J. Library of congress. USA.

Khedr, Z M.A. and S. Farid. 2002. Response of naturally virus infected tomato plants to yeast extract and phosphoric acid application. Annals of Agric. Sci. Moshtohor. Egypt. 38 (2): 927-939.

Marschner, H. 1995. Mineral Nutrition of Higher plants. $2^{\text {nd }}$ Ed. Academic press London New York. 889 P.

Martinez, M.T.; C. Romers and J. M. Gavilen. 1983. Interactions fosboraides hamicos. A. Findidad X1. 1: 61-62.

Mona, M., S.M.A. Kabeel, and M.A. Fayza . 2005. Effect of organic and biofertilizer on growth, yield and fruit quality of cucumber grown under clear polyethelene low tunnels. J. Agric . Sci. Mansoura Univ., 30 (5): 2827 - 2841

Murakami, Y.; K. Yokoigama; F. Kawai and H. Kawai. 1996. Lipid composition of commercial bakers, yeast having different tolerance in frozen doug. Bioscience, Biotechnology and chemistry, 60 (11): 1874-1876.

N. R. P. 1997. Nutrient Requirements of Domestic Animals, (Rabbits), No. 1 7th Rev. Ed., PP. 16-26. National Academy of Science, Washington, D.C.

Natio, K. S, K. Nagamo and H. Susuki. 1981. Effect of benzyl adenine on KNA and protein synthesis in inlactbean leaves at various stages of ageing. Physiol. Plant, 52: 343-348.

Padem, H and Ocal. 1999. Effects of humic acid applications on yield and some characteristics of processing tomato. Acta Horticulture 487, PP. 159-163.

Rubatzky, V.E and M. Tamaguchi. 1997. World vegetables, principles., production and nutritive values. Second edition. Chapman and Hall International Thomson Publishing. New York, U.S.A. PP. 843.

Soliman, E. M. 1996. Comparison of micronutrient application methods for cucumber production in acid land protected cultivation systems. Strategies for mark. Orient. Greenhouse production. Acta Hort. 434, ISHS 1996.

Sonmez, F. and M.A. Bozkurt. 2006. Lettuce grown on calcareous soils can beneft from sewage sludge. Acta Agriculturae Scondinaivca Section B-soil and plant science, 56 (1): 17-24.

Swann, P.F. 1975. The toxicology of nitrate, nitrite and N-nitroseo compound. J. Sci. Fd. Agric., 26. 1791.

Tarek, F.A.A.2003. The effect of some organic and inorganic fertilizers on plant growth and fruit quality of cucumber plant under plastic houses. M.Sc. Thesis, Faculty of Agric. Ain Shams Univ. 66 PP.

Troug, E and A. H. Mayer. 1939. Improvement in the deniess colorimeric method for phosphorus and arsenic. Indian Engineering chemical anrual Ed., I: 136-139.

Tufenkei, S; O. Turkmen, F. Sonmez, C. Erdinc and S. Sensoy. 2006. Effects of humic acid doses and application times on the plant growth, nutrient and heavy metal contents of lettuce grown on sewage sludge-applied soils. Fresenius environmental Bulletin, 15 (4): 295-300.

Wooley, J. T., G. P. Hicks and R. H. Hagean 1960. Rapid determination of nitrate and nitrite in plant material. J. Agric. Food Chem., 8: 481-482.

Yatskovskaya, P. Ya.; G.E. Solomko; I.V. Konoko and V.K. Yanchovskil. 1992. Chemical composition of protein concentrate from saccharomyces yeast molasses effect on immune response. Voprosy, pitaniya, No. 1: 63-67. 